\title{
Pertanggungjawaban Pimpinan BUMN/BUMD Berbentuk Perseroan Terbatas dalam Penyelesaian Tindak Pidana Korupsi
}

\author{
Ahmad Mufti \\ Fakultas Hukum Universitas Khairun.E-mail: ahmad mufti.unkhair@gmail.com \\ Sophian Y. Selajar \\ Fakultas Hukum Universitas Khairun. E-mail: sophianselajar@gmail.com \\ Muhammad Tabrani Mutalib \\ Fakultas Hukum Universitas Khairun.E-mail: firmahukum.mtm@gmail.com
}

\begin{abstract}
:
Juridically, the participation of the state in BUMN / BUMD Persero is the separated state assets. that wealth is legally the property of the Persero so that in its business actions if a loss arises, the loss is categorized as a loss of a BUMN / BUMD (business loss) corporation and not a State Loss which is subject to the APBN / $A P B D$ system. (2) The responsibility of the BUMN / BUMD Persero Directors as the management of the Company is the civil liability liability because the directors manage the Company's assets as a Civil Legal Entity. The Board of Directors does not manage state money if it is a management of BUMN / BUMD Persero but rather manages company money.
\end{abstract}

Keywords: State assets separated, Responsibilities of Directors, Corruption.

\section{PENDAHULUAN}

Perseroan Terbatas (PT) merupakan orang buatan (artificial person) karena itu tidak dapat melakukan tindakan sendiri, oleh sebab itu harus diwakili seseorang atau organ yang bertindak untuk dan atas nama perseroan terbatas. ${ }^{1}$ Organ tersebut adalah direksi yang akan melakukan pengurusan terhadap perseroan terbatas karena itu akan melakukan perbuatan hukum untuk dan atas nama perseroan.

Dalam Undang-Undang Nomor 40 Tahun 2007 tentang Perseroan Terbatas ( UU PT) ditentukan antara lain bahwa direksi adalah organ Perseroan Terbatas (PT) yang mempunyai kewenangan penuh untuk pengurusan perseroan. ${ }^{2}$ Pengurusan tersebut tidaklah dimaksudkan untuk kepentingan direksi atau pemegang saham tetapi selalu tertuju demi kepentingan perseroan. Direksi adalah organ yang mewakili perseroan selaku subyek

1 Lihat Rudhi Prasetya, “Kedudukan, Peran dan Pertanggungjawaban Pengurus Perseroan Terbatas", Makalah disampaikan pada Seminar Hukum Dagang, diselenggarakan Badan Pembinaan Hukum Nasional, Jakarta 29-30 Juli 1987), hlm. 4

${ }^{2}$ Pasal 1 angka 5 Undang-Undang No. 40 Tahun 2007 tentang Perseroan Terbatas, Lembaran Negara Republik Indonesia Tahun 2007 Nomor 106. 
hukum yang mandiri (persona standi judicio). Perseroan Terbatas (PT) dipandang sebagai subyek hukum yang mandiri dilepaskan dari manusia-manusia yang terkandung di dalamnya (separate legal personality). Pemberian status persona standi judicio dalam rangka penerapan konstruksi itu dijabarkan antara lain:

1. Perseroan terbatas bertanggung jawab atas semata-mata dengan harta kekayaan sendiri;

2. Pengurusan yang dilakukan dalam kerangka perseroan terbatas dilihat sebagai suatu "organ".

Merujuk pada Pasal 1 angka 1 UU PT, Perseroan Terbatas diartikan sebagai persekutuan modal, yang didirikan berdasarkan perjanjian, melakukan kegiatan usaha dengan modal yang seluruhnya terbagi dalam saham dan memenuhi persyaratan yang disebutkan dalam undang-undang serta peraturan pelaksanaan lainnya. ${ }^{3}$ Dari terminologi tersebut, PT dapat dikatakan sebagai persekutuan atau asosiasi modal. BUMN khususnya Persero pada dasarnya adalah sebuah korporasi, sebuah badan usaha berbadan hukum yang bertujuan untuk mencari keuntungan. Dengan memahami makna dan konsekuensi badan hukum, akan didapat pemahaman yang utuh tentang Persero. Pada dasarnya badan hukum adalah suatu badan yang dapat memiliki hak-hak dan kewajiban-kewajiban untuk melakukan suatu perbuatan seperti manusia, memiliki kekayaan sendiri, dan digugat dan menggugat di depan pengadilan.

Acapkali penegakan hukum terhadap kasus korupsi diberbagai BUMN/BUMD, khususnya Perusahaan (Persero) ternyata menimbulkan banyak kritik. Aparat penegak hukum seringkali dikatakan kurang memahami konsep badan hukum, seperti PT atau Perum serta konsekuensi yuridis penyertaan modal oleh negara dalam bentuk kekayaan negara yang dipisahkan dan Badan Usaha Milik Negara (BUMN). Akibatnya, tindakan aparat untuk memberantas korupsi di BUMN ternyata bertentangan Undang-Undang No. 40 Tahun 2007 tentang Perseroan Terbatas (merubah UU No. 1 Tahun 1995 tentang PT) dan UU No. 19 Tahun 2003 tentang Badan Usaha Milik Negara (UU BUMN) yang menjadi dasar eksistensi dan kegiatan perusahaan dimaksud.

Dalam prakteknya, upaya penegakan hukum baik itu penyidikan dan penuntutan oleh aparat penegak hukum terhadap kasus korupsi di berbagai BUMN, khususnya Perusahaan Perseroan (Persero) yang begitu gencar, ternyata menimbulkan banyak kritik. Aparat penegak hukum termasuk hakim juga seringkali dikatakan kurang memahami konsep dasar badan hukum (rechspersoon), seperti Perseroan Terbatas (PT) atau Perusahaan Umum (Perum) sehingga kurang dipahami juga konsekuensi yuridis penyertaan modal oleh negara dalam bentuk "kekayaan negara yang dipisahkan" pada BUMN. Akibatnya, tindakan aparat untuk memberantas korupsi terhadap aktivitas bisnis oleh BUMN/BUMD ternyata bertentangan UU No. 40 Tahun 2007 tentang Perseroan Terbatas dan UU No. 19 Tahun 2003 tentang Badan Usaha Milik Negara yang menjadi dasar eksistensi dan kegiatan perusahaan dimaksud.

Dalam konteks itulah, tulisan ini dimaksudkan untuk menelaah permasalahan makna kekayaan negara yang dipisahkan yang berkonsekuensi terhadap pertanggungjawaban Pimpinan BUMN/BUMD yang berbentuk PT dalam penyelesaian perkara korupsi dengan permasalahan hukum yang akan dijawab antara lain: (1) Apakah kerugian Perusahaan BUMN/BUMD dalam aktivitas bisnis merupakan kerugian keuangan negara? dan

\footnotetext{
${ }^{3}$ Pasal 1 angka 1 Undang-Undang No. 40 Tahun 2007 tentang Perseroan Terbatas, Lembaran Negara Republik Indonesia Tahun 2007 Nomor 106.
} 
bagaimana pertanggungjawaban hukum (legal liability) Pimpinan BUMN/BUMD yang berbentuk Perseroan Terbatas dalam penyelesaian perkara korupsi? Untuk menjawab isu hukum tersebut, Paradigma tulisan ini bersandar pada doktrin ultimum remidium atau ajaran yang memandang bahwa hukum pidana seharusnya berperan sebagai sarana, upaya, dan senjata pamungkas terakhir dalam menyelesaikan perkara korupsi. Titik tumpuan ini sengaja dipilih dengan reasoning membatasi ruang lingkup kajian sekaligus sebagai titik pangkal analisis. mengenai sistematika tulisan ini tersusun dari: I. Pendahuluan yang menerangkan latar belakang dan isu hukum yang dikaji, lalu II. Kajian Kepustakaan tentang konsep yang terdiri dari konsep Korporasi Sebagai Badan Hukum Privat, konsep Keuangan Negara dalam BUMN/BUMD Persero, Ruang Lingkup Keuangan Negara, Modal BUMN/BUMD Persero Sebagai Kekayaan Negara Yang Dipisahkan dan teori Tanggung Jawab Direksi Perseroan Terbatas serta Makna Kerugian Negara sebagai Unsur Tindak Tindak Pidana Korupsi. III. Pembahasan dan terakhir IV. Simpulan analisa.

\section{KAJIAN KEPUSTAKAAN}

\section{a. Korporasi Sebagai Badan Hukum}

Pada dasarnya badan hukum adalah suatu badan yang dapat memiliki hak-hak dan kewajiban-kewajiban untuk melakukan suatu perbuatan seperti manusia, memiliki kekayaan sendiri, dan digugat dan menggugat di depan pengadilan (rechtspersoon). ${ }^{4}$ Korporasi sebagai badan hukum memiliki beberapa ciri substantif yang melekat pada dirinya yaitu: ${ }^{5}$

a) Terbatasnya Tanggung Jawab

Pada dasarnya, para pendiri atau pemegang saham atau anggota suatu korporasi tidak bertanggungjawab secara pribadi terhadap kerugian atau utang korporasi. Jika badan usaha itu adalah PT, maka tanggung jawab pemegang saham hanya sebatas jumlah maksimum nominal saham yang ia kuasai. Selebihnya, ia tidak bertanggungjawab. ${ }^{6}$

b) Perpetual Succession

Bahwa sebagai sebuah korporasi yang eksis atas haknya sendiri, perubahan keanggotaan tidak memiliki akibat atas status atau eksistensinya. Bahkan, dalam konteks PT, pemegang saham dapat mengalihkan saham yang ia miliki kepada pihak ketiga. Pengalihan tidak menimbulkan masalah kelangsungan perseroan yang bersangkutan. Bahkan bagi PT yang masuk dalam kategori Terbuka dan sahamnya terdaftar di suatu bursa efek (listed), terdapat kebebasan untuk mengalihkan saham tersebut. $^{7}$

c) Memiliki Kekayaan Sendiri

Semua kekayaan yang ada dimiliki oleh badan itu sendiri, tidak oleh pemilik, oleh anggota atau pemegang saham. Ini adalah suatu kelebihan utama badan hukum. Dengan demikian, kepemilikan kekayaan tidak didasarkan pada anggota atau pemegang saham.

\footnotetext{
${ }^{4}$ Chidir Ali, Badan Hukum, Alumni, Bandung, 1987, hlm 19.

${ }^{5}$ David Kelly, et.al, Business Law, Cavendish Publishing Limited, London, 2002, hlm 343 - 345.

${ }^{6}$ Ridwan Khairandy, Korupsi di Badan Usaha Milik Negara Khususnya Perusahaan Perseroan: Suatu Kajian atas Makna Kekayaan Negara yang Dipisahkan dan Keuangan Negara”, Jurnal Hukum, Volume 16 nomor 1 april 2009....ibid., hlm. 74.

${ }^{7}$.Ibid., hlm. 75 .
} 
d) Memiliki Kewenangan Kontraktual serta Dapat Menuntut dan Dapat Dituntut atas Nama Dirinya Sendiri

Menurut Nindyo Pramono ${ }^{8}$ bahwa filosofi pendirian badan hukum adalah bahwa dengan kematian pendirinya, harta kekayaan badan hukum tersebut diharapkan masih dapat bermanfaat bagi orang lain. Oleh karena itu, hukum menciptakan suatu kreasi "sesuatu" yang oleh hukum kemudian dianggap atau diakui sebagai subjek mandiri seperti halnya orang (natuurlijk persoon). Kemudian "sesuatu" itu oleh ilmu hukum disebut sebagai badan hukum (rechtspersoon atau legal person). Agar badan hukum itu dapat bertindak seperti halnya orang alamiah, maka diperlukan organ sebagai alat bagi badan hukum itu untuk menjalin hubungan hukum dengan pihak ketiga. Agar badan hukum dapat berinteraksi dalam pergaulan hukum seperti membuat perjanjian, melakukan kegiatan usaha tertentu diperlukan modal. Modal awal badan hukum itu berasal dari kekayaan pendiri yang dipisahkan. Modal awal itu menjadi kekayaan badan hukum, terlepas dari kekayaan pendiri. Oleh karena itu, salah satu ciri utama suatu badan hukum seperti PT (termasuk PT Persero) adalah kekayaan yang terpisah itu, yaitu kekayaan terpisah kekayaan pribadi pendiri badan hukum itu. ${ }^{9}$

\section{b. Keuangan Negara dalam BUMN Persero}

Terminologi Keuangan Negara menurut Pasal 1 angka 1 Undang-Undang No. 17 Tahun 2003 tentang Keuangan Negara (UU Keuangan Negara) adalah semua hak dan kewajiban yang dapat dinilai dengan uang, serta segala sesuatu baik berupa uang maupun berupa barang yang dapat dijadikan milik Negara berhubungan dengan pelaksanaan hak dan kewajiban tersebut. ${ }^{10}$

(1) Pengertian dan Tujuan Badan Usaha Milik Negara (BUMN)

BUMN adalah badan usaha yang seluruh atau sebagian besar modalnya dimiliki oleh negara melalui penyertaan secara langsung yang berasal dari kekayaan negara yang dipisahkan. Berdasarkan pengertian tersebut, ada beberapa unsur yang menjadi suatu perusahaan dapat dikategorikan sebagai BUMN:

a) Badan usaha atau perusahaan; ${ }^{11}$

b) Modal badan usaha tersebut seluruhnya atau sebagian besar dimiliki oleh negara. Jika modal tersebut tidak seluruhnya dikuasai negara, maka agar tetap dikategorikan sebagai BUMN, maka negara minimum menguasai $51 \%$ modal tersebut.

c) Di dalam usaha tersebut, negara melakukan penyertaan secara langsung; Mengingat di sini ada penyertaan langsung, maka negara terlibat dalam menanggung risiko untung dan ruginya perusahaan. Menurut Penjelasan Pasal 4 ayat (3) UU No. 19 tahun 2003, pemisahan kekayaan negara untuk dijadikan penyertaan modal negara ke dalam BUMN hanya dapat dilakukan dengan cara penyertaan langsung negara

${ }^{8}$ Nindyo Pramono, "Kekayaan Negara Yang Dipisahkan Menurut UU No. 19 Tahun 2003 tentang BUMN", dalam Sri Rejeki Hartono, et.al, ed, Permasalahan Seputar Hukum Bisnis: Persembahan kepada Sang Maha Guru, Tanpa Penerbit, Jogjakarta, 2006, hlm 142.

${ }^{9}$ Ibid.

10 Pasal 1 angka 1 Undang-Undang No. 19 Tahun 2003 Tentang Badan Usaha Milik Negara, Lembaran Negara Republik Indonesia Tahun 2003 Nomor 70.

11 Oleh karena BUMN merupakan sebuah badan usaha perusahaan, maka sesuai dengan makna perusahaan atau badan, ia harus bertujuan untuk mendapatkan keuntungan atau profit, bukan untuk tujuan sosial. Lebih lanjut lihat Ridwan Khairandy, Pengantar Hukum Dagang, FH UII Press, Jogjakarta, 2006, hlm 
d) ke BUMN, sehingga setiap penyertaan tersebut harus ditetapkan dengan Peraturan Pemerintah (PP).

e) Modal penyertaan tersebut berasal dari kekayaan negara yang dipisahkan. Kekayaan yang dipisahkan di sini adalah pemisahan kekayaan negara dari Anggaran Pendapatan dan Belanja Negara (APBN) untuk dijadikan penyertaan modal negara pada BUMN untuk dijadikan modal BUMN. Setelah itu selanjutnya pembinaan dan pengelolaannya tidak lagi didasarkan pada sistem APBN, namun pembinaan dan pengelolaannya pada prinsip-prinsip perusahaan yang sehat (good corporate governance). ${ }^{12}$

Suatu badan usaha dapat dikategorikan sebagai BUMN harus merupakan perusahaan yang modalnya berasal dari penyertaan langsung dari negara. Jika ada sebuah PT yang didirikan oleh BUMN, maka tidak dapat dikatakan sebagai BUMN, karena penyertaan modalnya bukan berasal dari negara, tetapi dari BUMN. UU No. 19 Tahun 2003 secara tegas menyebut bahwa modal BUMN adalah penyertaan langsung dari kekayaan negara yang dipisahkan. Dengan pemisahan ini, maka begitu negara melakukan penyertaan di perusahaan tersebut, penyertaan tersebut demi hukum menjadi kekayaan badan usaha. Pemisahan kekayaan ini merupakan konsekuensi hukum bagi sebuah badan hukum. Dengan demikian, secara yuridis modal tadi sudah menjadi kekayaan perusahaan, bukan kekayaan negara lagi. Penyertaan modal negara dalam rangka pendirian atau penyertaan pada BUMN menurut Pasal 4 jo. Penjelasan Pasal 4 ayat (2) Huruf b UU No. 19 Tahun 2003, bersumber dari:

a) Anggaran Pendapatan dan Belanja Negara, termasuk dalam APBN yaitu meliputi proyek-proyek APBN yang dikelola oleh BUMN dan/atau piutang negara pada BUMN yang dijadikan sebagai penyertaan modal.

b) Kapitalisasi cadangan: Kapitalisasi cadangan ini adalah penambahan modal disetor yang berasal dari cadangan.

c) Sumber lainnya, termasuk dalam kategori sumber lainnya ini antara lain keuntungan revaluasi aset. ${ }^{13}$

(2) Pengertian Badan Usaha Milik Daerah (BUMD)

Menurut Pasal 1 angka 40 Undang-Undang No. 23 Tahun 2014 Tentang Pemerintahan Daerah (UU Pemda) adalah BUMD adalah badan usaha yang seluruh atau sebagian besar modalnya dimiliki oleh Daerah. ${ }^{14}$ Lebih lanjut, Pasal 409 huruf (a) menyatakan bahwa ketika UU No. 23 Tahun 2014 mulai berlaku, maka UU No. 5 Tahun 1962 tentang Perusahaan Daerah dicabut dan dinyatakan tidak berlaku. Tetapi peraturan perundang-undangan pelaksaan dari UU No. 5 Tahun 1962 tentang Perusahaan Daerah masih tetap berlaku sepanjang belum diganti dan tidak bertentangan dengan ketentuan dalam Undang-Undang No. 23 Tahun 2014 Tentang Pemerintahan Daerah.

(3) Ruang Lingkup Keuangan Negara

Dalam Pasal 1 angka 1 UU Keuangan Negara, pengertian keuangan Negara adalah semua hak dan kewajiban yang dapat dinilai dengan uang, serta segala sesuatu baik

\footnotetext{
${ }^{12}$ Lihat Ridwan Khairandy, Korupsi...ibid., hlm. 78.

${ }^{13}$ Lihat Pasal 4 Undang-Undang No. 19 Tahun 2003 Tentang Badan Usaha Milik Negara, Lembaran Negara Republik Indonesia Tahun 2003 Nomor 70.

${ }^{14}$ Pasal 1 angka 40 Undang-Undang Republik Indonesia No. 23 tahun 2014 Tentang Pemerintahan daerah, Lembaran Negara Republik Indonesia Tahun 2014 Nomor 244.
} 
berupa uang maupun berupa barang yang dapat dijadikan milik Negara berhubungan dengan pelaksanaan hak dan kewajiban tersebut. ${ }^{15}$

Dalam Pasal 2 huruf g UU No.17 Tahun 2003 tentang Keuangan Negara, mengatur ruang lingkup keuangan Negara yang salah satunya meliputi: Kekayaan Negara/daerah yang dikelola sendiri atau oleh pihak lain berupa uang, surat berharga, piutang, barang serta hak-hak lain yang dapat dinilai dengan uang, termassuk kekayaan yang dipisahkan pada perusahan Negara/daerah. ${ }^{16}$

(4) Modal BUMN/BUMD Persero Sebagai Kekayaan Negara Yang Dipisahkan

Modal BUMN/BUMD berasal dari kekayaan negara atau daerah yang dipisahkan. ${ }^{17}$ Penyertaan modal negara dalam rangka pendirian atau penyertaan pada BUMN bersumber dari: (a) Anggaran Pendapatan dan Belanja Negara; (b) kapitalisasi cadangan; (c) sumber lainnya. ${ }^{18}$

Setiap penyertaan modal negara dalam rangka pendirian BUMN/BUMD maupun Perseroan Terbatas yang dananya berasal dari Anggaran Pendapatan dan Belanja Negara (APBN) atau Anggaran Pendapatan dan Belanja Daerah (APBD) ditetapkan dengan Peraturan Pemerintah. ${ }^{19}$ Setiap perubahan penyertaan modal negara, baik berupa penambahan maupun pengurangan, termasuk perubahan struktur kepemilikan negara atas saham Persero atau Perseroan Terbatas, ditetapkan dengan Peraturan Pemerintah. ${ }^{20}$ Dikecualikan bagi penambahan penyertaan modal negara yang berasal dari kapitalisasi cadangan dan sumber lainnya. ${ }^{21}$

\section{c. Tanggung Jawab Direksi Perseroan Terbatas}

Dalam Pasal 1 angka 9 UU BUMN disebutkan Direksi adalah organ BUMN yang bertanggung jawab atas pengurusan BUMN untuk kepentingan dan tujuan BUMN, serta mewakili BUMN baik di dalam maupun di luar pengadilan. ${ }^{22}$ Pengurusan BUMN dilakukan oleh Direksi dan Direksi bertanggung jawab penuh atas pengurusan BUMN untuk kepentingan dan tujuan BUMN serta mewakili BUMN, baik di dalam maupun di luar pengadilan. Dalam melaksanakan tugasnya, anggota Direksi harus mematuhi anggaran dasar BUMN dan peraturan perundang-undangan serta wajib melaksanakan prinsip-prinsip profesionalisme, efisiensi, transparansi, kemandirian, akuntabilitas, pertanggungjawaban, serta kewajaran. $^{23}$

Direksi merupakan badan pengurus perseroan yang berhak, dan berwenang untuk menjalankan perusahaan, bertindak untuk dan atas nama perseroan. ${ }^{24}$ Direksi merupakan dewan direktur (boar of directors) yang dapat terdiri atas satu atau beberapa orang

\footnotetext{
${ }^{15}$ Lihat Pasal 1 angka 1 Undang-Undang No, 17 Tahun 2003 tentang Keuangan Negara, Lembaran Negara Republik Indonesia Tahun 2003 Nomor 47

${ }^{16}$ Lihat Pasal 2 huruf g Undang-Undang No. 19 Tahun 2003 Tentang Badan Usaha Milik Negara, Lembaran Negara Republik Indonesia Tahun 2003 Nomor 70.

${ }^{17}$ Ibid Lihat Pasal 4 ayat (1)

${ }^{18}$ Ibid Pasal 4 ayat (2)

${ }^{19}$ Ibid Pasal 4 ayat (3)

${ }^{20}$ Ibid Pasal 4 ayat (4)

${ }^{21}$ Ibid Pasal 4 ayat (5)

${ }^{22}$ Ibid Pasal 1 angka 9

23 Pasal 5 Undang-Undang No. 19 Tahun 2003 Tentang Badan Usaha Milik Negara, Lembaran Negara Republik Indonesia Tahun 2003 Nomor 70.

${ }^{24}$ Ahmad Yani dan Gunawan Widjaja, Seri Hukum Bisnis Perseroan Terbatas, PT. Raja Grafindo Persada, Jakarta, 2000, hlm. 96-97.
} 
direktur. Apabila Direksi lebih dari satu orang direktur, maka salah satunya menjadi Direktur Utama atau Presiden Direktur dan yang lainnya menjadi disrektur atau wakil direktur. ${ }^{25}$ Pasal 1 ayat (4) Undang-Undang Nomor 40 Tahun 2007 tentang Perseroan Terbatas menyatakan bahwa Direksi adalah organ perseroan yang bertanggung jawab penuh atas pengurusan perseroan untuk kepentingan dan tujuan perseroan serta mewakili perseroan baik di dalam maupun di luar pengadilan sesuai dengan ketentuan Anggaran Dasar. $^{26}$

\section{d. Makna Kerugian Negara sebagai Unsur Tindak Tindak Pidana Korupsi}

\section{Pengertian Tindak Pidana Korupsi}

Secara normatif yuridis pengertian tindak pidana korupsi terdapat dalam Bab II UndangUndang Nomor 31 Tahun 1999 tentang Pemberantasan Korupsi (selanjutnya disebut UU PTPK). Apa yang dimaksud dengan tindak pidana korupsi seperti yang dimaksud oleh UU PTPK adalah tindak pidana seperti yang terdapat dalam Pasal 2, Pasal 5, Pasal 6, Pasal 7, Pasal 8, Pasal 9, Pasal 10, Pasal 11, Pasal Pasal 12, Pasal 13, dan Pasal 14. Dalam UU No. 20 Tahun 2001 Tentang Perubahan atas UU PTPK disebutkan antara lain bahwa di antara Pasal 12 dan Pasal 13, disisipkan Pasal baru, yaitu Pasal 12B. Dengan demikian, sesudah diadakan perubahan dengan UU No 20 Tahun 2001, yang dimaksud dengan tindak pidana korupsi seperti yang dimaksud oleh UU No. 31 Tahun 1999 (UU PTPK) adalah tindak pidana seperti yang terdapat dalam Pasal 2, Pasal 3, Pasal 5, Pasal 6, Pasal 7, Pasal 8, Pasal 9, Pasal 10, Pasal 11, Pasal 12, Pasal 12 B, Pasal 13, dan Pasal 14. ${ }^{27}$

\section{Subjek Hukum Tindak Pidana Korupsi}

Berdasarkan ketentuan Pasal 1 angka (1), (2), (3) Undang-Undang Nomor 31 Tahun 1999 tentang Pemberantasan Tindak Pidana Korupsi jo. Undang-Undang Nomor 20 Tahun 2001, yang menjadi subjek hukum Tipikor adalah: (a) Korporasi; (b) Pegawai Negeri, dan (c) Setiap Orang. Sementara itu, dengan diratifikasinya UN Convention Against Corruption dengan UU Nomor 7 Tahun 2006, dalam konvensi mana kerugian negara tidak mutlak merupakan unsur tindak pidana korupsi (it shall not be necessary), tetapi harus melibatkan public official, maka unsur "setiap orang" dalam Pasal 2 ayat (1) dan Pasal 3 UU PTPK harus juga ditafsirkan (dimaknai) dalam kaitan dengan perbuatan public official. Dengan demikian, secara konseptual unsur "setiap orang" yang dimaksud Pasal 1 ayat (3) UU PTPK harus dimaknai subyek hukum publik atau pihak yang menduduki jabatan (pejabat) atau pegawai negeri.

\section{Kerugian Negara sebagai Unsur Delik Korupsi}

Pengertian keuangan Negara berdasarkan perspektif hukum pidana adalah suatu pernbuatan yang menyimpang terhadap penggunaan dan pengelolaan keuangan Negara sehingga dapat dikualifikasikan sebagai perbuatan merugikan Negara atau dapat merugikan Negara sebagai tindak pidana korupsi, dengan pemenuhan unsur-unsur: pertama, perbuatan tersebut merupakan perbuatan melawan hukum dalam pengertian materil atau penyalahgunaan wewenang, kesempatan atau sarana yang ada padanya, dan kedua, para pihak ada yang diperkaya dan diuntungkan, baik si pelaku sendiri, orang lain

\footnotetext{
25 Lihat Ridwan Khairandy, Perseroan Terbatas: Doktrin Peraturan Perundang-Undangan dan Yurisprudensi, Kreasi Total Media, Yogyakarta, 2008, hlm. 204

${ }^{26}$ Lihat Pasal 1 ayat (4) Undang-Undang Nomor 40 Tahun 2007 tentang Perseroan Terbatas, Lembaran Negara Republik Indonesia Tahun 2007 Nomor 106.

${ }^{27}$ R. Wiyono, 2008, Pembahasan Undang-Undang Pemberantasan Tindak Pidana Korupsi, Sinar Grafika, Jakarta, hlm. 10.
} 
atau korporasi. Hal tersebut diatur dalam Pasal 2 ayat (1) dan Pasal 3 UU No. 31 Tahun 1999 jo UU No. 20 Tahun 2001 tentang Pemberantasan Tindak Pidana Korupsi.

\section{Metode Penelitian}

Tipe penelitian dalam tulisan ini adalah Peneltian hukum (legal research), bukan penelitian sosio-legal, olehnya itu tidak menguraikan hipotesa. Paradigma tulisan ini bersandar pada doktrin ultimum remidium atau ajaran yang memandang bahwa hukum pidana seharusnya berperan sebagai sarana, upaya, dan senjata pamungkas terakhir dalam menyelesaikan perkara korupsi.

Adapun pendekatan yang digunakan dalam penelitian ini antara lain: pertama, pendekatan Undang-Undang (statuta approach) yaitu dilakukan dengan menelaah pelbagai peraturan perundang-undangan yang terkait dengan isu hukum pada rumusan masalah. kedua, pendekatan kasus (case approach) yaitu dengan cara menelaah Putusan-putusan pengadilan yang telah berkekuatan hukum tetap (inkracht) antara lain: (1) Putusan Pengadilan Negeri Jakarta Pusat No. 36/Pid.B/TPK/2012/PN.JKT.PST jo. Putusan Kasasi No. 417K/Pid.Sus/2014 jo. Putusan Peninjauan Kembali Mahkamah Agung No. 41 PK/Pid.Sus/2015; dan (2) Putusan Pengadilan Negeri Ternate No. 10/Pid.SusTPK/2016/PN Tte. Telaah pelbagai putusan tersebut dimaksudkan agar dapat diketahui pertimbangan hukum (ratio decidendi) Majelis Hakim Pengadilan sebagai basis argumentasi yang berujung pada amar putusannya. ketiga, pendekatan konseptual (conceptual approach) dengan beranjak dari konsep-konsep atau doktrin ahli hukum telah menjadi doctorum comunis opinio berlaku universal.

Objek penelitian berupa norma-norma hukum yang terkait dengan permasalahan hukum pada rumusan masalah baik dalam bentuk regeling (peraturan perundang-undangan) maunpun vonnis (putusan pengadilan) yang telah berkekuatan hukum tetap.

Bahan hukum dalam penelitian ini terdiri dari bahan hukum primer: (1) peraturan perundang-undangan (regeling), putusan pengadilan/yurisprudensi terkait (yurisprudensi); (2) Bahan hukum sekunder yang digunakan bersumber dari pelbagai literatur, antara lain: buku, jurnal, karya ilmiah (disertasi, tesis, dan skripsi) yang bersangkut paut dengan penelitian ini.

Pengelolaan dan penyajian bahan hukum dengan cara pertama-tama mengindentifikasi isu hukum dalam penelitian ini lalu mengeliminasi hal-hal yang tidak relevan dengan isu hukum. Langkah selanjutnya, setelah mengumpul bahan-bahan hokum, kemudian dilakukanlah interpretasi (legal interpetation) dengan pendekatan-pendekatan yang telah disebutkan di atas terhadap rumusan masalah tentang tanggung jawab pimpinan BUMN/BUMD Persero dalam penyelesaian perkara korupsi di Indonesia.

Adapun langkah terakhir yang dilakukan yakni memberikan preskripsi (judgment) berdasarkan argumentasi yang telah dibangun di dalam kesimpulan. langkah-langkah ini sesuai dengan karakter ilmu hukum sebagai ilmu yang bersifat preskriptif. ${ }^{28}$ Setelah menarik kesimpulan sebagai jawaban dari permasalahan hukum, maka diberikan rekomendari langkah atau upaya hukum apa yang dilakukan untuk membenahi kekeliruan maupun kekurangan praktik penegakaan hukum di bidang korupsi.

\footnotetext{
${ }^{28}$ Peter Mahmud Marzuki, Penelitian Hukum, edisi revisi, cet-9, (Jakarta: Prenadamedia group, 2014), hlm. 213.
} 


\section{PEMBAHASAN}

\section{a. Kerugian BUMN/BUMD Persero Bukanlah Kerugian Negara}

BUMN/BUMD mempunyai peranan penting dalam penyelenggaraan perekonomian nasional guna mewujudkan kesejahteraan masyarakat. Pelaksanaan peran BUMN/BUMD dalam perekonomian nasional untuk mewujudkan kesejahteraan masyarakat belum optimal. $^{29}$ BUMN/BUMD yang seluruh atau sebagian besar modalnya berasal dari kekayaan negara/daerah yang dipisahkan merupakan salah satu pelaku ekonomi dalam sistem perekonomian nasional, di samping usaha swasta dan koperasi. Dalam menjalankan kegiatan usahanya, BUMN, swasta dan koperasi melaksanakan peran saling mendukung berdasarkan demokrasi ekonomi. Sedangkan BUMD adalah badan usaha yang seluruh atau sebagian besar modalnya dimiliki oleh daerah. ${ }^{30}$ Daerah dapat melakukan penyertaan modal pada BUMN atau BUMD. ${ }^{31}$

Perbedaan BUMN dengan BUMD terletak pada bentuk perusahaannya. BUMN terdiri dari Perseron Terbatas (PT) dan Perusahaan Umum (Perum). ${ }^{32}$ BUMN yang berbentuk Persero (PT), modalnya terbagi dalam saham yang seluruh atau paling sedikit $51 \%$ (lima puluh satu persen) sahamnya dimiliki oleh Negara Republik Indonesia yang tujuan utamanya mengejar keuntungan. ${ }^{33}$ Selain itu, ada juga BUMN yang berbentuk Persero Terbuka (Tbk), yang mana modal dan jumlah pemegang sahamnya memenuhi kriteria tertentu atau Persero yang melakukan penawaran umum di bidang pasar modal. ${ }^{34}$ Sedangkan BUMN yang berbentuk Perum adalah BUMN yang seluruh modalnya dimiliki negara dan tidak terbagi atas saham, yang bertujuan untuk kemanfaatan umum berupa penyediaan barang dan/atau jasa yang bermutu tinggi dan sekaligus mengejar keuntungan berdasarkan prinsip pengelolaan perusahaan. ${ }^{35}$

Mengenai BUMD, Pemerintah Daerah dapat mendirikan BUMD yang ditetapkan melalui Perda. ${ }^{36}$ Bentuk BUMD dapat terdiri atas perusahaan umum Daerah (Perumda) atau perusahaan perseroan daerah (Perusda). ${ }^{37}$ BUMD yang berbentuk Perumda adalah yang seluruh modalnya dimiliki oleh satu Daerah dan tidak terbagi atas saham. ${ }^{38}$ Sedangkan BUMD yang berbentuk Perusda (PT), modalnya terbagi dalam saham yang seluruhnya atau paling sedikit 51\% (lima puluh satu persen) sahamnya dimiliki oleh satu Daerah dan setelah ditetapkan dengan Perda, pembentukan badan hukumnya dilakukan berdasarkan ketentuan Peraturan Perundang-undangan mengenai Perseroan Terbatas (PT). ${ }^{39}$

\footnotetext{
${ }^{29}$ Penjelasan Umum Angka I Undang-Undang No. 19 Tahun 2013 tentang Badan Usaha Milik Negara, Tambahan Lembaran Negara Republik Indonesia Nomor 4297.

${ }^{30}$ Pasal 1 angka 40 Undang-Undang Republik Indonesia No. 23 tahun 2014 Tentang Pemerintahan daerah, Lembaran Negara Republik Indonesia Tahun 2014 Nomor 244.

${ }^{31}$ Ibid Pasal 304

${ }^{32}$ Pasal 9 Undang-Undang No. 19 Tahun 2003 Tentang Badan Usaha Milik Negara, Lembaran Negara Republik Indonesia Tahun 2003 Nomor 70.

${ }^{33}$ Pasal 1 angka 2 Undang-Undang No. 19 Tahun 2003 Tentang Badan Usaha Milik Negara, Lembaran Negara Republik Indonesia Tahun 2003 Nomor 70.

${ }^{34}$ Ibid Pasal 1 angka 3

${ }^{35}$ Ibid Pasal 1 angka 4

36 Pasal 331 ayat (1) dan (2) Undang-Undang Republik Indonesia No. 23 tahun 2014 Tentang Pemerintahan daerah, Lembaran Negara Republik Indonesia Tahun 2014 Nomor 244

${ }^{37}$ Ibid Pasal 331 ayat (3)

${ }^{38}$ Ibid Pasal 331 ayat (1)

39 Pasal 339 ayat (1) dan ayat (2) Undang-Undang Republik Indonesia No. 23 tahun 2014 Tentang Pemerintahan daerah, Lembaran Negara Republik Indonesia Tahun 2014 Nomor 244
} 
Atas dasar itulah, baik BUMN ${ }^{40}$ maupun BUMD yang berbentuk PT terikat kepada ketentuan dan prinsip-prinsip yang berlaku bagi suatu perseroan terbatas sebagaimana diatur dalam UU No. 40 Tahun 2007 tentang Perseroan Terbatas (UU PT). Dengan kata lain, pembinaan dan pengelolaannya tidak lagi didasarkan pada sistem APBN, namun pembinaan dan pengelolaannya pada prinsip-prinsip perusahaan yang sehat (good corporate governance). Dalam Pasal 4 UU PT menegaskan bahwa terhadap suatu Perseroan berlaku UU PT selain juga Anggaran Dasar Persero dan Peraturan Perundangundangan lainnya. ${ }^{41}$ Lebih ditegaskan lagi dalam Pasal 154 UU PT bahwa mengenai Perseroan Terbuka (Tbk) berbentuk PT juga berlaku ketentuan UU PT jika tidak diatur lain oleh UU di bidang pasar modal. Meskipun Peraturan perundang-undangan di bidang pasar modal dapat mengecualikan ketentuan UU PT akan tetapi, tidak boleh bertentangan dengan asas-asas hukum Perseroan dalam UU PT. ${ }^{42}$

Sementara itu, kekayaan negara yang dipisahkan adalah kekayaan negara yang berasal dari APBN untuk dijadikan penyertaan modal negara pada Persero dan/atau Perum serta perseroan terbatas lainnya. ${ }^{43}$ Dengan demikian, modal $\mathrm{BUMN}^{44} / \mathrm{BUMD}$ merupakan kekayaan negara yang dipisahkan. Penyertaan modal negara dalam rangka pendirian atau penyertaan pada BUMN bersumber dari:

a. Anggaran Pendapatan dan Belanja Negara (termasuk dalam APBN meliputi pula proyek-proyek APBN yang dikelola oleh BUMN dan/atau piutang negara pada BUMN yang dijadikan sebagai penyertaan modal negara);

b. kapitalisasi cadangan (yang dimaksud dengan kapitalisasi cadangan adalah penambahan modal disetor yang berasal dari cadangan);

c. sumber lainnya (yang dimaksud dengan sumber lainnya adalah keuntungan revaluasi aset). ${ }^{45}$

Setiap penyertaan modal negara dalam rangka pendirian BUMN Persero yang dananya berasal dari APBN ditetapkan dengan PP. ${ }^{46}$ Jika ada sebuah PT yang didirikan oleh BUMN, maka PT tersebut tidak dapat dikatakan sebagai BUMN, karena penyertaan modalnya bukan berasal langsung dari kas negara, tetapi dari kas BUMN. Misalnya PT Pupuk Kalimantan Timur (PT PKT) tidak dapat disebut sebagai BUMN, karena dari Anggaran Dasar PT tersebut, terlihat bahwa modal perseroan berasal dari penyertaan PT Pupuk Sriwijaya (Persero) dan koperasi karyawan. Dalam putusan perkara korupsi, Direktur Utama PT Pupuk Kalimantan Timur Omay K Wiriatmadja, Pengadilan Negeri Jakarta Selatan berpendapat, bahwa PT PKT bukan BUMN. Hal ini didasarkan pada fakta bahwa saham PT PKT tidak dimiliki oleh pemerintah. 99,99 \% saham PT PKT dimiliki oleh PT Pupuk Sriwijaya (Persero). Penyertaan modal PT Pupuk Sriwijaya tidak dapat dikategorikan sebagai penyertaan langsung negara pada PT PKT. Penyertaan tersebut tidak

\footnotetext{
${ }^{40}$ Pasal 11 Undang-Undang No. 19 Tahun 2003 Tentang Badan Usaha Milik Negara, Lembaran Negara Republik Indonesia Tahun 2003 Nomor 70.

${ }^{41}$ Pasal 4 Undang-Undang No. 40 Tahun 2007 tentang Perseroan Terbatas, Lembaran Negara Republik Indonesia Tahun 2007 Nomor 106.

42 Pasal 154 Undang-Undang No. 40 Tahun 2007 tentang Perseroan Terbatas, Lembaran Negara Republik Indonesia Tahun 2007 Nomor 106.

${ }^{43}$ Pasal 1 angka 10 Undang-Undang No. 19 Tahun 2003 Tentang Badan Usaha Milik Negara, Lembaran Negara Republik Indonesia Tahun 2003 Nomor 70.

${ }^{44}$ Ibid Pasal 4 ayat (1)

${ }^{45}$ Ibid Pasal 4 ayat (2)

${ }^{46}$ Ibid Pasal 4 ayat (3)
} 
berasal dari APBN. ${ }^{47}$ Hal itu juga diperkuat dengan pertimbangan hukum (ratio decidendi) Mahkamah Konstitusi dalam Putusannya No. 01/PHPU-PRES/XVII/2019, tanggal 24 juni 2019 yang menyatakan bahwa "..Bank BNI Syariah dan Bank Syariah Mandiri bukan merupakan BUMN, melainkan anak perusahaan BUMN yang merupakan Bank Syariah.” Adapun penyertaan modal pada BUMD dapat bersumber dari: (a) Penyertaan modal Daerah; (b) Pinjaman; (c) Hibah; dan (d) Sumber modal lainnya seperti kapitalisasi cadangan, keuntungan revaluasi aset; dan agio saham. ${ }^{48}$

Penyertaan modal daerah tersebut kemudian ditetapkan dengan PERDA dan dapat dilakukan untuk pembentukan BUMD dan penambahan modal BUMD. Penyertaan modal daerah dapat berupa uang dan barang milik Daerah. Barang milik Daerah dinilai sesuai nilai riil pada saat barang milik Daerah akan dijadikan penyertaan modal. Nilai riil diperoleh dengan melakukan penafsiran harga barang milik Daerah sesuai dengan ketentuan peraturan perundang-undangan. ${ }^{49}$ Dengan demikian, BUMD Persero dibentuk berdasarkan modal dari kekayaan negara yang dipisahkan sebagaiman diuraikan diatas, maka BUMD Persero secara hukum bertindak sebagai badan hukum (rechtspersoon/legal person) yang memiliki keududukan yang mandiri sebagai subyek hukum (persona standi judicio) dalam interaksi pergaulan hukum atau perbuatan keperdataan lainya (business).

Atas dasar itulah, secara yuridis, modal yang disertakan ke dalam BUMN/BUMD Persero bukan lagi menjadi kekayaan Negara, tetapi menjadi kekayaan BUMN/BUMD Persero itu sendiri. Di sini terjadi pemisahan kekayaan antara kekayaan pemegang saham $51 \%$ melalui penyertaan dari kas Negara/Daerah menjadi modal BUMN/BUMD Persero. Dengan karakteristik seperti itu, maka ketika negara menyertakan modalnya dalam bentuk saham ke dalam BUMN/BUMD Persero dari kekayaan negara yang dipisahkan, kekayaan itu demi hukum berubah bentuk menjadi kekayaan BUMN/BUMD Persero dan bukan lagi kekayaan negara, akibat hukumnya, segala kekayaan yang didapat baik melalui penyertaan negara maupun yang diperoleh dari kegiatan bisnis BUMN/BUMD Persero secara yuridis telah menjadi kekayaan BUMN/BUMD Persero itu sendiri. ${ }^{50}$

Berkenaan dengan itu, menurut Erman Rajagukguk bahwa tuduhan korupsi yang dikenakan terhadap tindakan Direksi atau pimpinan BUMN/BUMD dalam transaksitransaksi yang dikatakan merugikan kerugian negara merupakan suatu kesalahan menafsirkan pengertian keuangan negara. ${ }^{51}$ Lebih lanjut Erman menyebutkan kesalahan terjadi juga dalam PP No. 14 Tahun 2005 tentang Tata Cara Penghapusan Piutang Negara/Daerah. Pasal 19 PP tersebut menyatakan bahwa penghapusan secara bersyarat dan penghapusan secara mutlak piutang Perusahaan Negara/Daerah dilakukan sesuai dengan ketentuan peraturan perundang-undangan yang berlaku. Selanjutnya Pasal 20 PP tersebut juga menyatakan bahwa tata cara dan penghapusan secara bersyarat dan penghapusan secara mutlak atas piutang Perusahaan Negara/Daerah yang pengurusan piutang diserahkan kepada Panitia Urusan Piutang Negara (PUPN) diatur lebih lanjut dengan Peraturan Menteri Keuangan. PP tersebut tidak memisahkan kekayaan BUMN Persero dan kekayaan

\footnotetext{
${ }^{47}$ Ridwan Khairandy, Korupsi...Op, Cit., hlm. 77

48 Pasal 332 Undang-Undang Republik Indonesia No. 23 tahun 2014 Tentang Pemerintahan daerah, Lembaran Negara Republik Indonesia Tahun 2014 Nomor 244

${ }^{49}$ Pasal 333 Undang-Undang Republik Indonesia No. 23 tahun 2014 Tentang Pemerintahan daerah, Lembaran Negara Republik Indonesia Tahun 2014 Nomor 244

${ }^{50}$ Ridwan Khairandy, Korupsi...Op, Cit., hlm. 81

51 Erman Rajagukguk, Nyanyi Sunyi Kemerdekaan Menuju Indonesia Negara Hukum Demokratis, Fakultas Hukum Universitas Indonesia, Lembaga Studi Hukum dan Ekonomi, Depok, 2006, hlm. 387, Lihat juga Ridwan Khairandy, Korupsi...ibid.
} 
negara sebagai pemegang saham. ${ }^{52}$ Pemerintah menyadari kesalahan pemikiran tersebut ketika menghadapi kredit bermasalah (non performing loan) PT. Bank Rakya (Persero), PT. Bank Negara Indonesia, dan PT. Bank Mandiri (Persero). Ketika pemerintah melalui mengambil inisiatif untuk menghapus Pasal 19 dan 20 PP a quo, Menteri Keuangan menyatakan:

"Selanjutnya, pengurusan piutang perusahaan negara/daerah dilakukan berdasarkan UU Perseroan Terbatas dan UU Badan Usaha Milik Negara. Jadi, disebutkan bahwa aturan yang mengatur bank-bank BUMN adalah UU Perseroan Terbatas dan Undang-Undang Badan Usaha Milik Negara." 53

Usulan perubahan tersebut sempat mengundang perdebatan di dalam Komisi XI DPR karena dianggap membatalkan Pasal 2 Butir g Undang-Undang No, 17 Tahun 2003 tentang Keuangan Negara (UU Keuangan negara). Untuk itu kemudian diusulkan untuk meminta fatwa Mahkamah Agung (MA). MA sendiri dalam fatwanya membenarkan alasan Menteri Keuangan di atas. Akhirnya, pemerintah melalui PP No. 33 Tahun 2006 menghapus Pasal 19 dan Pasal 20 PP 14 Tahun 2005. Selanjutnya Pasal II ayat (1) PP No. 33 Tahun 2006 tentang Perubahan atas Peraturan Pemerintah No. 14 Tahun 2005 tentang Tata Cara Penghapusan Piutang Negara/Daerah menentukan pada saat berlakunya PP ini mulai berlaku:

a. Pengurusan Piutang Negara/Daerah untuk selanjutnya dilakukan sesuai dengan ketentuan peraturan perundang-undangan yang berlaku di bidang Perseroan Terbatas dan Badan Usaha Milik Negara beserta peraturan pelaksanaannya;

b. Pengurusan ..."54

Dengan ketentuan ini terlihat jelas piutang-piutang BUMN Persero tidak dapat dikategorikan sebagai piutang negara, tetapi piutang-piutang BUMN sendiri. Oleh karena piutang merupakan bagian kekayaan perseroan, maka kepemilikan keseluruhan kekayaan yang dimiliki BUMN adalah BUMN itu sendiri sebagai sebuah Perseroan dan bukan kekayaan negara yang dipisahkan. Permasalahannya sekarang peraturan perundangundangan mana yang harus dipakai menyelesaikan permasalahan yang menyangkut keuangan negara dikaitkan kekayaan negara. Kekayaan negara yang dipisahkan dalam BUMN harus diperlakukan sebagai aturan khusus (lex specialis), sehingga berdasar asas lex specialis derogat legi generale, maka UU BUMN harus menjadi dasar penyelesaiannya. Kemudian dikaitkan dengan waktu pengundangannya atau pemberlakuannya, UU BUMN juga diundangkan lebih belakangan, maka berdasar asas lex posteriori derogat legi priori, UU BUMN harus menjadi dasar hukumnya.

Keuangan Negara dalam oleh UU Tipikor dimaknai sangat luas meliputi seluruh kekayaan negara dalam bentuk apapun, sedangkan UU Keuangan Negara memberikan batasan keuangan negara yang lebih sempit yaitu semua hak dan kewajiban negara yang dapat dinilai dengan sejumlah uang. dari dua definisi itu saja dapat menimbulkan perdebatan alot. Sebab frasa "seluruh kekayaan negara" dengan "hak dan kewajiban negara" secara gramatikal memiliki makna yang berbeda, sebab elemen dari frasa "Seluruh kekayaan

\footnotetext{
${ }^{52}$ Ibid, hlm 388 .

53 Ibid., hlm 389 mengutip Media Indonesia, 11 Juli 2006. Lihat pula Ridwan Khairandy, Korupsi...Op,Cit. hlm. 84

${ }^{54}$ Lihat Pasal II ayat (1) huruf a Peraturan Pemerintah No. 33 Tahun 2006 tentang Perubahan atas Peraturan Pemerintah No. 14 Tahun 2005 tentang Tata Cara Penghapusan Piutang Negara/Daerah, Lembaran Negara Republik Indonesia Tahun 2006 Nomor 83
} 
negara" unsurnya mengandung makna "seluruh harta kekayaan negara". Sedangkan elemen frasa "hak dan kewajiban negara" bermakna adalah "segala hak dan kewajiban yang melekat pada negara".

Secara yuridis, hak dan kewajiban itu erat kaitannya dengan subjek hukum baik itu orang (natuurlijkpersoon) atau badan hukum (rechtspersoon) karena hanya subjek hukum yang dapat menyandang hak dan kewajiban. Selain itu, yang dimaksud harta kekayaan adalah sesuatu atau objek yang dapat dimiliki atau dikuasai oleh subjek hukum. ${ }^{55}$ Olehnya itu, dapat disimpulkan bahwa UU PTPK mengartikan keuangan negara dari sudut objeknya, sedangkan UU Keuangan Negara mengartikan keuangan negara dari subjeknya sehingga melahirkan penafsiran yang berbeda tentang Keuangan Negara pada tataran pelaksanaan UU karena tidak menggunakan tolak ukur yang sama dan dapat dipastikan dalam pelaksanaannya akan menimbulkan permasalahan ${ }^{56}$ menyangkut tolak ukur kerugian negara.

Terkait hal itu, Pasal 1 angka 20 Undang-Undang No. 1 Tahun 2004 Tentang Perbendaharaan Negara (UU Perbendaharaan Negara) jo. Pasal 1 angka 15 UndangUndang No. 15 Tahun 2006 Tentang Badan Pemeriksa Keuangan Negara (UU BPK) ${ }^{57}$ menyatakan bahwa:

"Kerugian Negara/Daerah adalah kekurangan uang, surat berharga, dan barang, yang nyata dan pasti jumlahnya sebagai akibat perbuatan melawan hukum baik sengaja maupun lalai." 58

Sedangkan sebab kerugian negara diatur dalam Pasal 59 ayat (1) UU Perbendaharaan Negara yaitu:

"Setiap kerugian negara/daerah yang disebabkan oleh tindakan melanggar hukum atau kelalaian seseorang harus segera diselesaikan sesuai dengan ketentuan perundangundangan yang berlaku. ${ }^{59}$

Penjelasan: Kerugian negara dapat terjadi karena pelanggaran hukum atau kelalaian pejabat negara atau pegawai negeri bukan bendahara dalam rangka pelaksanaan kewenangan administratif atau oleh bendahara dalam rangka pelaksanaan kewenangan kebendaharaan. ${ }^{60}$

Berdasarkan ketentuan tersebut, menjadi terang bahwa syarat kerugian keuangan negara harus dibuktikan secara nyata (actual loss) dan bukan hanya sekedar potential loss. Hal ini berkesesuaian dengan penjelasan frasa "secara nyata telah ada kerugian negara" yang tercantum dalam penjelasan Pasal 32 ayat (1) UU Tipikor bahwa "kerugian yang sudah dapat dihitung jumlahnya berdasarkan hasil temuan instansi yang berwenang atau akuntan publik yang ditunjuk." Selain itu juga, dalam Konvensi PBB Anti Korupsi (UN Convention Against Corruption sebagaiman telah diratifikasi dan disahkan dengan UU

\footnotetext{
${ }^{55}$ Nindyo Pramono, Op.Cit., hlm. 136.

${ }^{56}$ Ibid., hlm. 137

${ }^{57}$ Pasal 1 angka 15 Undang-Undang No. 15 Tahun 2006 Tentang Badan Pemeriksa Keuangan Negara, Lembaran Negara Republik Indonesia Tahun 2006 Nomor 85.

${ }^{58}$ Ibid Pasal 1 angka 20

${ }^{59}$ Ibid Pasal 59 ayat (1)

${ }^{60}$ Ibid Penjelasan Pasal 59 ayat (1)
} 
Nomor 7 Tahun 2006) yang juga memasukkan unsur kerugian negara dalam delik korupsi, kerugian negara tersebut harus benar-benar sudah terjadi atau nyata. ${ }^{61}$

Jika aparat penegak hukum masih menganut paham kekayaan BUMN/BUMD Persero adalah kekayaan negara, maka negara juga harus bertanggungjawab terhadap seluruh utang yang dimiliki BUMN/BUMD. Pemahaman demikian dapat menyebabkan APBN/APBD akan terkuras untuk membayar utang-utang BUMN/BUMD Persero yang mengalami rugi. Oleh karena itu, untuk mencegah kesalahan seperti maka, kerugian bisnis (business loss) BUMN/BUMD Persero tidak boleh disamakan menjadi kerugian Negara. Sebab seluruh aktivitas bisnis BUMN/BUMD Persero tunduk pada prinsip business judgment rule dan bukan prinsip penyelenggaraan pemerintahan (government judgement rules). ${ }^{62}$

Dengan demikian, akibat hukum dari pengelolaan kekayaan negara yang dipisahkan di BUMN/BUMD Persero adalah pengelolaan tidak menggunakan sistem APBN/APBD (government judgement rules) tetapi menggunakan sistem business judgment rule yang tunduk pada UU Perseroan Terbatas. ${ }^{63}$ Secara yuridis penyertaan negara dalam suatu badan usaha yang berbentuk Persero merupakan kekayaan negara yang dipisahkan. Begitu negara menyertakan kekayaan tersebut, kekayaan itu demi hukum menjadi kekayaan Persero. Persero sebagai badan hukum memiliki kedudukan mandiri. Secara fisik kekayaan negara dalam Persero itu berwujud saham yang tunduk pada rezim hukum prinsip dan norma tentang perseroan terbatas.

\section{b. TANGGUNGJAWAB PIMPINAN BUMN/BUMD DALAM PENYELESAIAN PERKARA KORUPSI}

Unsur kerugian negara menjadi unsur penting dalam pemberantasan tindak pidana korupsi selain suap, gratifikasi dll di Indoensia, bahkan dalam Pasal 2 ayat (1) dan Pasal (3) UU Tipikor, bila unsur "kerugian negara" tidak terpenuhi, maka terdakwa tidak dapat dikenakan sanksi pidana.

Sebelum adanya Putusan Mahkamah Konstitusi No. 25/PUU-XIV/2016, ${ }^{64}$ kejahatan 'korupsi' diterjemahkan sebagai tindakan yang bertentangan dengan norma hukum pidana dalam arti formil (formele wederrechtelijkheid) dan terhadap perbuatan tersebut diancam dengan sanksi pidana. Ketentuan Pasal 2 ayat (1) dan Pasal 3 UU Tipikor. Tafsir seperti itu dipertegas lagi dengan Putusan MK No. 003/PUU-4/2006 yang menyatakan bahwa suatu perbuatan itu dikategorikan melawan hukum jika perbuatan tersebut bertentangan dengan undang-undang (wettelijk straftbepaling), dengan konsekuensi bahwa penjelasan Pasal 2 ayat (1) UU No. 31 Tahun 1999 mengenai sifat melawan hukum materil tidak lagi

${ }^{61}$ Lihat paragraf [3.10.6] Putusan Mahkamah Konstitusi No. 25/PUU-XIV/2016, diputus rabu tanggal 25 Januari 2017, hlm 114

${ }^{62}$ Mengenai doktrin business judgment rule, lihat Pasal 97 Undang-Undang No. 40 Tahun 2007 tentang Perseroan Terbatas, Lembaran Negara Republik Indonesia Tahun 2007 Nomor 106. Doktrin Business judgment rule diadopsi didalam Pasal 97 tersebut intinya bahwa Direksi BUMN bertanggungjawab atas pengurusan perusahaan yang dikelolanya. Pengurusan dilakukan dengan dengan itikad baik dan penuh tanggung jawab. Setiap anggota Direksi bertanggung jawab penuh secara pribadi atas kerugian Perseroan apabila yang bersangkutan bersalah atau lalai menjalankan tugasnya.

${ }^{63}$ Heryanto Sijabat, Akibat Hukum Pengelolaan Kekayaan Negara Yang Dipisahkan, http://www.bppk.kemenkeu.go.id/publikasi/artikel/147-artikel-anggaran-dan-perbendaharaan/21026-akibathukum-pengelolaan-kekayaan-negara-yang-dipisahkan, Tanggal 25 Agustus 2019

${ }^{64}$ Putusan MK No. 25/PUU-XIV/2016 tentang Pengujian UU No. 31 Tahun 1999 tentang Pemberantasan Tindak Pidana Korupsi sebagaimana diubah dengan UU No. 20 Tahun 2001 tentang Perubahan Atas UU No. 31 Tahun 1999 tentang Pemberantasan Tindak Pidana Korupsi terhadap UUD NRI Tahun 1945 
memiliki kekuatan mengikat dan yang masih berlaku hanyalah perbuatan hukum dalam arti formil. ${ }^{65}$

Paradigma pemberantasan korupsi seperti itu kemudian mengalami pergeseran lagi sejak lahirnya Undang-Undang No. 30 Tahun 2014 Tentang Administrasi Pemerintahan (UU Administrasi Pemerintahan) menyebabkan paradigma pemberantasan tindak pidana korupsi di Indonesia mengalami pergeseran dari yang mengutamakan pendekatan pidana menjadi mengutamakan pendekatan hukum administrasi negara, atau dengan kata lain, dari yang mengutamakan penghukuman pidana penjara menjadi yang mengutamakan pengembalian uang negara. Disamping itu, adanya Putusan MK No. 25/PUU-XIV/2016, lebih mempertegas bahwa Pasal 2 ayat (1) dan Pasal 3 UU TIPIKOR merupakan tindak pidana materiil. Kata "dapat" dalam Pasal 2 ayat (1) dan Pasal 3 UU Tipikor sebagaimana disebutkan di atas pernah diputus MK dalam Putusan No. 003/PUU-IV/2006 tanggal 25 Juli 2006, dengan menyatakan tidak bertentangan dengan hak atas kepastian hukum yang adil sebagaimana dimaksudkan oleh Pasal 28D ayat (1) UUD 1945 sepanjang ditafsirkan sesuai dengan tafsiran MK (conditionally constitutional), yakni bahwa unsur kerugian negara harus dibuktikan dan harus dapat dihitung, meskipun sebagai perkiraan atau meskipun belum terjadi. Menurut MK, bahwa unsur merugikan keuangan negara tidak lagi dipahami sebagai perkiraan (potential loss) namun harus dipahami benar-benar sudah terjadi atau nyata (actual loss) untuk dapat diterapkan dalam tindak pidana korupsi.

Bahwa adanya kata "dapat” dalam Pasal 2 ayat (1) dan Pasal 3 UU Tipikor membuat delik dalam kedua pasal tersebut menjadi delik formil. Hal itu menurut MK dalam praktik seringkali disalahgunakan untuk menjangkau banyak perbuatan yang diduga merugikan keuangan negara, termasuk terhadap kebijakan atau keputusan diskresi atau pelaksanaan asas freies Ermessen yang diambil bersifat mendesak dan belum ditemukan landasan hukumnya, sehingga seringkali terjadi kriminalisasi dengan dugaan terjadinya penyalahgunaan wewenang. ${ }^{66}$ Demikian juga terhadap kebijakan yang terkait dengan bisnis namun dipandang dapat merugikan keuangan negara maka dengan pemahaman kedua pasal tersebut sebagai delik formil seringkali dikenakan tindak pidana korupsi. Kondisi tersebut tentu dapat menyebabkan pejabat publik takut mengambil suatu kebijakan atau khawatir kebijakan yang diambil akan dikenakan tindak pidana korupsi, sehingga di antaranya akan berdampak pada stagnasi proses penyelenggaraan negara, rendahnya penyerapan anggaran, dan terganggunya pertumbuhan investasi. Kriminalisasi kebijakan terjadi karena terdapat perbedaan pemaknaan kata "dapat" dalam unsur merugikan keuangan negara dalam tindak pidana korupsi oleh aparat penegak hukum, sehingga seringkali menimbulkan persoalan mulai dari perhitungan jumlah kerugian negara yang sesungguhnya sampai kepada lembaga manakah yang berwenang menghitung kerugian negara. Oleh sebab itu, pencantuman kata "dapat" dalam Pasal 2 ayat (1) dan Pasal 3 UU Tipikor menimbulkan ketidakpastian hukum dan telah secara nyata bertentangan dengan jaminan bahwa setiap orang berhak atas rasa aman dan perlindungan dari ancaman ketakutan sebagaimana ditentukan dalam Pasal 28G ayat (1) UUD 1945. Kata "dapat" dalam Pasal 2 ayat (1) dan Pasal 3 UU Tipikor juga bertentangan dengan prinsip perumusan tindak pidana yang harus memenuhi prinsip hukum harus tertulis (lex scripta), harus ditafsirkan seperti yang dibaca (lex stricta), dan tidak multitafsir (lex certa), oleh

${ }^{65}$ Ridwan, Persinggungan Antar Bidang Hukum Dalam Perkara Korupsi, Cetakan Pertama, FH UII Press, Yogyarkarta, 2016, hlm 37.

${ }^{66}$ Ibid., 
karenanya bertentangan dengan prinsip negara hukum sebagaimana ditentukan dalam Pasal 1 ayat (3) UUD 1945. Lebih lanjut MK menegaskan sebagai berikut:

"[3.10.6] Bahwa penerapan unsur merugikan keuangan dengan menggunakan konsepsi actual loss menurut MK lebih memberikan kepastian hukum yang adil dan bersesuaian dengan upaya sinkronisasi dan harmonisasi instrumen hukum nasional dan internasional, seperti dengan UU Administrasi Pemerintahan sebagaimana diuraikan dalam paragraf [3.10.2] dan paragraf [3.10.3] di atas, Undang-Undang Nomor 1 Tahun 2004 tentang Perbendaharaan Negara (UU Perbendaharaan Negara) dan UndangUndang Nomor 15 Tahun 2006 tentang Badan Pemeriksa Keuangan (UU BPK) serta Konvensi Perserikatan Bangsa- Bangsa Anti Korupsi, 2003 (United Nation Convention Against Corruption, 2003) yang telah diratifikasi Indonesia melalui Undang-Undang Nomor 7 Tahun 2006."67

Dengan demikian, kata "dapat" tidak lagi menjadi bagian unsur delik (elementen delicten) dalam rumusan Pasal 2 ayat 1 dan Pasal 3 UU Tipikor. Oleh karena itu, bila merujuk Pasal 2 ayat (1) dan Pasal 3 UU PTPK maka, tindakan badan/pejabat pemerintahan atau pegawai negeri dapat dikatakan kejahatan korupsi dengan syarat adanya perbuatan melawan hukum (wederrechtelijkheid) dan/atau penyalahgunaan wewenang (detournement de puvoir) yang secara aktual merugikan keuangan negara atau perekonomian negara. Terkait unsur "melawan hukum" dan "penyalahgunaan wewenang" tersebut, Nur Basuki Winarno mengatakan bahwa:

“...Secara implisit penyalahgunaan wewenang in haeren dengan melawan hukum, karena penyalahgunaan wewenang esensinya merupakan perbuatan melawan hukum. Unsur "melawan hukum" merupakan genusnya, sedangkan "penyalahgunaan wewenang" adalah spesiesnya. Sifat in haeren penyalahgunaan wewenang dan melawan hukum tidaklah berarti 'melawan hukum' terbukti tidak secara mutatis mutandis 'penyalahgunaan wewenang' terbukti, tetapi untuk sebaliknya unsur 'penyalahhgunaan wewenang' terbukti, maka unsur 'melawan hukum' tidak perlu dibuktikan karena dengan sendirinya unsur 'melawan hukum' telah terbukti. Dalam hal unsur 'penyalahhgunaan wewenang' tidak terbukti maka belum tentu unsur 'melawan hukum' tidak terbukti." 68

Berdasarkan pandangan di atas, tampak bahwa antara ketentuan Pasal 2 yang mengandung unsur "melawan hukum" dengan Pasal 3 yang mengandung unsur "menyalahgunakan wewenang" pada dasarnya adalah sejenis dan hanya memiliki perbedaan sifat. Dengan demikian, dakwaan seharusnya berbentuk dakwaan alternatif sebab bertujuan supaya antara dakwaan yang satu dengan yang lain saling mengecualikan (one that substitutes for another) dan memberikan pilihan kepada hakim untuk menentukan dakwaan mana yang tepat dipertanggungjawabkan kepada terdakwa sehubungan dengan tindak pidana yang dilakukannya. ${ }^{69}$

Adapun mengenai tanggung jawab pimpinan BUMN/BUMD Persero apabila dalam suatu perkara korupsi dikenakan Pasal 2 ayat (1) dan/atau Pasal 3 UU PTPK. Untuk BUMN/BUMD Persero, Pimpinan yang bertanggung jawab dalam suatu Perseoran

${ }^{67}$ Putusan Mahkamah Konsitusi No. 25/PUU-XIV/2016, diputus rabu tanggal 25 Januari 2017, hlm. 114.

${ }^{68}$ Ridwan HR, Hukum...Ibid, hlm. 377-378.

69 Lihat Yahya Harahap, Pembahasan Permasalahan dan Penerapan KUHAP: Penyidikan dan Penuntutan, Edisi Kedua, Cetakan Kedua belas, Jakarta: Sinar Grafika, 2009, hlm. 399-400. 
Terbatas ialah organ perusahaan yang disebut Direksi. Menurut Pasal 1 angka 5 UU PT menyebutkan bahwa direksi adalah organ perseroan yang berwenang dan bertanggung jawab penuh atas pengurusan perseroan untuk kepentingan perseroan, sesuai dengan maksud dan tujuan perseroan serta mewakili perseroan, baik di dalam maupun di luar pengadilan sesuai dengan ketentuan anggaran dasar. ${ }^{70}$

Direksi sebagai pengurus persero menjalankan pengurusan perseroan untuk kepentingan persero dan sesuai dengan maksud dan tujuan perseroan. Direksi berwenang menjalankan pengurusan sesuai dengan kebijakan yang dipandang tepat, dalam batas yang ditentukan dalam UU PT dan/atau Anggaran Dasar Perseroan. Direksi terdiri atas satu orang anggota Direksi atau lebih. Perseroan yang kegiatan usahanya berkaitan dengan menghimpun dan/atau mengelola dana masyarakat atau perseroan yang menerbitkan surat pengakuan utang kepada masyarakat, atau Perseroan Terbuka (Tbk) wajib mempunyai paling sedikit 2 (dua) orang anggota Direksi. Dalam hal Direksi terdiri atas 2 (dua) anggota Direksi atau lebih, pembagian tugas dan wewenang pengurusan di antara anggota Direksi ditetapkan berdasarkan keputusan RUPS. RUPS tidak menetapkan, pembagian tugas dan wewenang anggota Direksi ditetapkan berdasarkan keputusan Direksi. ${ }^{71}$ Seseorang yang dapat diangkat menjadi anggota Direksi adalah orang perseorangan yang cakap melakukan perbuatan hukum, kecuali dalam waktu lima tahun sebelum pengangkatannya pernah:

a. dinyatakan pailit;

b. menjadi anggota Direksi atau anggota Dewan Komisaris yang dinyatakan bersalah menyebabkan suatu Perseroan dinyatakan pailit; atau

c. dihukum karena melakukan tindak pidana yang merugikan keuangan negara dan/atau yang berkaitan dengan sektor keuangan. ${ }^{72}$

Ketentuan persyaratan tidak mengurangi kemungkinan instansi teknis yang berwenang menetapkan persyaratan tambahan berdasarkan peraturan perundang-undangan. Pemenuhan persyaratan dibuktikan dengan surat yang disimpan oleh Perseroan. ${ }^{73}$

Pertanggungjawaban anggota direksi dalam menjalankan tugasnya sebagai pengurus Perseroan adalah pertanggungjawaban hukum keperdataan. Karena direksi mengelola kekayaan Perseroan sebagai Badan Hukum Keperdataan. Direksi tidak mengelola uang negara apabila sebagai pengurus BUMN/BUMD Persero melainkan mengelola uang perusahaan, sebab secara yuridis, modal yang disertakan ke dalam perseroan bukan lagi menjadi kekayaan orang menyertakan modal, tetapi menjadi kekayaan perseroan itu sendiri. Di sini terjadi pemisahan kekayaan antara kekayaan pemegang saham $51 \%$ dalam hal ini adalah Negara atau Daerah dengan perseroan itu sendiri (in casu BUMN/BUMD). Dengan karakteristik seperti itu, maka ketika negara menyertakan modalnya dalam bentuk saham ke dalam Persero dari kekayaan negara yang dipisahkan, karena hukum kekayaan itu menjadi kekayaan Persero. Tidak lagi menjadi kekayaan negara. Konsekuensinya, segala kekayaan yang didapat baik melalui penyertaan negara maupun yang diperoleh dari kegiatan bisnis Persero, demi hukum menjadi kekayaan Persero itu sendiri dan bukan

${ }^{70}$ Pasal 1 angka 5 Undang-Undang Nomor 40 Tahun 2007 Tentang Perseroan Terbatas, Lembaran Negara Republik Indonesia Tahun 2007 Nomor 106

${ }^{71}$ Pasal 92 Undang-Undang Nomor 40 Tahun 2007 Tentang Perseroan Terbatas, Lembaran Negara Republik Indonesia Tahun 2007 Nomor 106

${ }^{72}$ Pasal 93 ayat (1) Undang-Undang Nomor 40 Tahun 2007 Tentang Perseroan Terbatas, Lembaran Negara Republik Indonesia Tahun 2007 Nomor 106

${ }_{73}$ Pasal 93 ayat (2) dan (3) Undang-Undang Nomor 40 Tahun 2007 Tentang Perseroan Terbatas, Lembaran Negara Republik Indonesia Tahun 2007 Nomor 106 
keuangan negara lagi. Pemahanan tentang persinggungan bidang-bidang hukum inilah yang kurang dipahami penegak hukum sehingga dalam penegakan tindak pidana korupsi seringkali tidak proporsional menerapkan ketentuan-ketentuan UU PTPK. Akibat dari kesilapan penegak hukum terkait konsekuensi yuridis penyertaan modal oleh negara dalam bentuk kekayaan negara yang dipisahkan sebagai Modal BUMN/BUMD adalah tindakan aparat untuk memberantas korupsi di BUMN/BUMD ternyata bertentangan UU PT dan UU BUMN sendiri dasar eksistensi perusahaan milik negara.

\section{PENUTUP}

Berdasarkan uraian dalam pembahasan tersebut, dapat disimpulkan bahwa terdapat perbedaan makna antara kerugian negara dengan kerugian perusahaan BUMN/BUMD Persero. Secara yuridis penyertaan negara dalam suatu badan usaha yang berbentuk Persero merupakan kekayaan negara yang dipisahkan. Begitu negara menyertakan kekayaan tersebut, kekayaan itu demi hukum menjadi kekayaan Persero. Persero sebagai badan hukum memiliki kedudukan mandiri. Secara fisik kekayaan negara dalam Persero itu berwujud saham, bukan kekayaan Persero (in casu BUMN/BUMD) yang bersangkutan. akibat hukum dari pengelolaan kekayaan negara yang dipisahkan di BUMN/BUMD adalah pengelolaan tidak menggunakan sistem APBN/APBD tetapi menggunakan sistem yang tunduk pada UU Perseroan Terbatas. Meskipun BUMN/BUMD pengelolaannya dengan cara perusahaan terbatas umumnya, tetapi APBN/APBD menerima bagian pemerintah atas laba BUMN, sehingga dalam tindakan bisnisnya apabila timbul kerugian maka kerugian tersebut dikategorikan sebagai kerugian perusahaan Persero BUMN/BUMD (business loss) dan bukan sebagai Kerugian Negara yang tunduk pada sistem APBN/APBD (Keuangan Negara). Pertanggungjawaban pimpinan in casu Direksi BUMN/BUMD Persero dalam menjalankan tugasnya sebagai pengurus Perseroan adalah pertanggungjawaban hukum keperdataan karena direksi mengelola kekayaan Perseroan sebagai Badan Hukum Keperdataan. Direksi tidak mengelola uang negara apabila sebagai pengurus BUMN/BUMD Persero melainkan mengelola uang perusahaan, Pemahaman tentang persinggungan bidang-bidang hukum inilah yang kurang dipahami penegak hukum sehingga dalam penegakan tindak pidana korupsi seringkali tidak proporsional menerapkan ketentuan Pasal 2 ayat (1) dan Pasal 3 UU Tipikor. Upaya hukum yang dapat dilakukan negara terhadap Pimpinan BUMN/BUMD Persero yang karena tindakannya menimbulkan kerugian bagi Persero mestinya tidak dilakukan atas dasar tindak pidana korupsi sebagaimana Pasal 2 ayat (1) dan Pasal 3 UU PTPK. Negara sebagai pemegang saham dapat melakukan gugatan perdata terhadap pimpinan/direksi tersebut karena melanggar kewajiban fiduciary duty. Pimpinan yang bersangkutan dapat pula dituntut secara pidana misalnya atas tuduhan melakukan penggelapan, pemalsuan data atau laporan keuangan, dan tindak pidana perbankan.

\section{DAFTAR PUSTAKA}

\section{Buku}

Ali, Chidir, Badan Hukum, Alumni, Bandung, 1987.

Harahap, Yahya, Pembahasan Permasalahan dan Penerapan KUHAP: Penyidikan dan Penuntutan, Edisi Kedua, Cetakan Kedua belas, Jakarta: Sinar Grafika, 2009.

HR, Ridwan, Hukum Administrasi Negara, Cetakan Kesepuluh, Jakarta: Rajawali Pers, 2014. 
Persinggungan Antar Bidang Hukum Dalam Perkara Korupsi, Cetakan Pertama, FH UII Press, Yogyarkarta, 2016.

Kelly, David, et.al, Business Law, Cavendish Publishing Limited, London, 2002.

Khairandy, Ridwan, Pengantar Hukum Dagang, FH UII Press, Jogjakarta, 2006.

, Perseroan Terbatas: Doktrin Peraturan Perundang-Undangan dan Yurisprudensi, Kreasi Total Media, Yogyakarta, 2008.

Marzuki, Peter Mahmud, Penelitian Hukum, edisi revisi, cetakan ke-9, (Jakarta: Prenadamedia group, 2014).

Rajagukguk, Erman, Nyanyi Sunyi Kemerdekaan Menuju Indonesia Negara Hukum Demokratis, Fakultas Hukum Universitas Indonesia, Lembaga Studi Hukum dan Ekonomi, Depok, 2006.

Pramono, Nindyo, "Kekayaan Negara Yang Dipisahkan Menurut UU No. 19 Tahun 2003 tentang BUMN", dalam Sri Rejeki Hartono, et.al, ed, Permasalahan Seputar Hukum Bisnis: Persembahan kepada Sang Maha Guru, Tanpa Penerbit, Jogjakarta, 2006.

Yani, Ahmad dan Gunawan Widjaja, Seri Hukum Bisnis Perseroan Terbatas, PT. Raja Grafindo Persada, Jakarta, 2000.

Wiyono, R., 2008, Pembahasan Undang-Undang Pemberantasan Tindak Pidana Korupsi, Sinar Grafika, Jakarta.

\section{Jurnal}

Khairandy, Ridwan, "Korupsi di Badan Usaha Milik Negara Khususnya Perusahaan Perseroan: Suatu Kajian atas Makna Kekayaan Negara yang Dipisahkan dan Keuangan Negara”, Jurnal Hukum, Volume 16 nomor 1 april 2009.

Prasetya, Rudhi, "Kedudukan, Peran dan Pertanggungjawaban Pengurus Perseroan Terbatas", Makalah disampaikan pada Seminar Hukum Dagang, diselenggarakan Badan Pembinaan Hukum Nasional, Jakarta 29-30 Juli 1987.

\section{Karya illmiah dan Internet}

Harum, Wilibrodus, 2014, “Interpretasi Unsur Kerugian Keuangan Negara Dalam Perkara Tindak Pidana Korupsi Yang Terjadi Di Badan Usaha Milik Negara Berbentuk Persero", Skripsi di Universitas Atma Jaya Yogyakarta.

Kompas, Sabtu 24 Februari 2007.

Heryanto Sijabat, Akibat Hukum Pengelolaan Kekayaan Negara Yang Dipisahkan, http://www.bppk.kemenkeu.go.id/publikasi/artikel/147-artikel-anggaran-danperbendaharaan/21026-akibat-hukum-pengelolaan-kekayaan-negara-yangdipisahkan, Tanggal 25 Agustus 2019 